\title{
PRINCÍPIOS FREIREANOS PARA A FORMAÇÃO DE UM PROFESSOR DE LÍNGUAS LIBERTADOR
}

Tainá Almeida*

RESUMO: As discussões empreendidas neste artigo dizem respeito às exigências pedagógicas freireanas para a formação de um professor libertador. Em tempos tão controversos no cenário educativo brasileiro, apresento e discuto neste ensaio oito saberes formadores docentes, aos quais aqui chamo de princípios freireanos, ao refletir acerca de uma prática educadora crítica cujo projeto de sociedade esteja voltado para a formação de cidadãos críticos, capazes de ler a sua realidade social local e de transformá-la. Ancorada na obra de Paulo Freire, discuto teoricamente os seguintes princípios: Criticidade; Reflexão crítica sobre a prática; Reconhecimento e assunção da identidade cultural; Apreensão da realidade; Segurança, competência profissional e generosidade; Convicção de que a mudança é possível; Reconhecer que a educação é ideológica; e Disponibilidade para o diálogo. A vida e a obra de Freire desafiam a todos nós, professores, a construir nossa prática pedagógica de forma coerente, reflexiva e sociopoliticamente comprometida.

PALAVRAS-CHAVE: Princípios freireanos; Pedagogia libertadora; Formação de professores.

\footnotetext{
* Doutoranda em Língua e Cultura pela Universidade Federal da Bahia (Ufba). Mestre em Letras: Cultura, Educação e Linguagens pela Universidade Estadual do Sudoeste da Bahia (Uesb).
} 


\section{Iniciando o diálogo}

Paulo Reglus Neves Freire, estimado educador e filósofo pernambucano, marcou a história da educação brasileira ao deixar um respeitável legado pedagógico teórico e prático para as futuras gerações de educadores. Sua obra é o pilar que sustentará as discussões empreendidas neste artigo, cujo objetivo é o de apresentar alguns saberes que Freire considerava imprescindíveis para a formação e práxis do professor.

As teorias de Freire, e sua prática, estavam voltadas para a formação do educando enquanto cidadão. Sua preocupação pedagógica era a de fomentar a construção da consciência do indivíduo a fim de que este fosse capaz de ler não somente as letras, mas o mundo a sua volta. Para ele, o papel do docente é o de educar para a vida, ou seja, a preocupação do professor deve estar voltada para a formação integral do aluno enquanto sujeito de sua história e não vítima dela.

A fim de orientar a prática pedagógica de docentes, Freire dedicou a sua vida a praticar uma pedagogia libertadora e a teorizar sobre ela, sempre ancorado em sua vivência enquanto professor. Sua pedagogia era voltada para a libertação dos oprimidos e, também, do opressor. Seu discurso, coerente com sua prática, alcançou reconhecimento mundial e a relevância de sua obra ecoa até hoje numa sociedade em que temas como opressão, criticidade, conscientização e libertação conservam-se pertinentes. Questões das quais o professor de línguas, como qualquer outro, não pode se eximir.

Pela importância de seu legado ético e, portanto, político para a pedagogia, este artigo apresentará, de forma resumida, alguns dos vários princípios pedagógicos pensados, vividos e transmitidos por Freire como saberes necessários à formação e prática educativa de todo e qualquer professor cujo objetivo seja a libertação dos discentes, bem como a sua própria. Destaco aqui aqueles princípios que julgo mais apropriados ou essenciais para que o professor de línguas, sejam elas maternas ou estrangeiras, combata a alienação social, intelectual e cultural em que ele e seus discentes possam estar inseridos. 


\section{A pedagogia de Paulo Freire}

[...] encaramos a educação como um esforço de libertação do homem $e$ não como um instrumento a mais de sua dominação. (FREIRE, 1967, p. 121)

Para compreender a pedagogia proposta por Freire é necessário visitar as suas produções escritas, algumas das quais decorrentes de discursos orais proferidos pelo professor. Apesar da diversa produção que deixou, há um único espírito crítico voltado para a conscientização das pessoas que pode ser sentido em toda a sua obra.

Em seu primeiro livro, Educação como prática da liberdade, publicado em 1967, Freire descreve o cenário da sociedade brasileira daquela época, uma sociedade construída sobre as bases da colonização e cuja mente funcionava de acordo com as regras do colonizador. Era-lhe, portanto, necessária uma educação para a liberdade. Para Freire (1967, p. 35 e 36, grifo meu), este era o dilema enfrentado pela sociedade da época:

Opção por uma sociedade parcialmente independente ou opção por uma sociedade que se "descolonizasse" cada vez mais. Que cada vez mais cortasse as correntes que a faziam e fazem permanecer como objeto de outras, que lhe são sujeitos. Este é o dilema básico, que se apresenta, hoje, de forma iniludível, aos países subdesenvolvidos ao Terceiro Mundo. A educação das massas se faz, assim, algo de absolutamente fundamental entre nós. Educação que, desvestida da roupagem alienada e alienante, seja uma força de mudança e de libertação. A opção, por isso, teria de ser também, entre uma "educação" para a "domesticação", para a alienação, e uma educação para a liberdade. "Educação" para o homem-objeto ou educação para o homem-sujeito.

Nesse trecho é possível perceber a lógica da pedagogia freireana: uma pedagogia totalmente comprometida com a realidade local, com os conflitos de classe, com a sociedade, com os valores e direitos humanos; uma pedagogia para a vida. Nesse seu primeiro livro, fica clara a visão crítica com que Freire enxerga o mundo e, no caso, a sociedade brasileira, assim como seu nível de opressão. O Brasil de 1967, ano da publicação desse livro, era um Brasil "sob botas" que vivia sob o regime militar opressor que limitava o pensamento crítico e cuja educação era voltada para a manutenção dos militares no poder. 
A luta de Freire por uma educação libertadora na qual as massas ocupam lugar central e a quem é restituído o direito de pensar e falar está amplamente manifestada nesse livro.

A partir da análise do cenário social brasileiro que se apresentava à época, Paulo Freire traz à luz o papel central da educação na modificação da história. Mas não é qualquer educação que tem esse poder. Há que se fazer uma educação voltada para a libertação, uma educação revolucionária que se preocupa em conscientizar o cidadão de seu papel de sujeito na história e não de produto dela.

O trabalho pedagógico de Freire estava ancorado no esforço para a tomada de consciência do cidadão brasileiro da realidade que o cercava e na conversão de sua ingenuidade em criticidade concomitantemente com sua alfabetização. Está patente na pedagogia freireana a necessidade que se tem de que, para que o aprendizado aconteça, ambos os sujeitos (educador e educando) devem estar conscientes da realidade na qual estão inseridos. Por isso, o conteúdo programático adotado em sala de aula deve ser construído em conjunto por estes sujeitos, não podendo ser-lhes imposto de fora, e os temas debatidos não podem ser alheios à realidade local, pois somente estando inseridos nela podem produzir sentido e mediar o aprendizado. O esquecimento desses pressupostos por parte do educador o faria incorrer fatalmente nos erros da educação alienada. (FREIRE, 1967)

A pedagogia de Paulo Freire, que é a que ele denomina pedagogia do oprimido, se vale de alguns princípios básicos para existir, dentre eles, a superação da dicotomia opressor/oprimido, como dito anteriormente; a luta contra a educação "bancária" alienante que não consegue exercer qualquer relação com a realidade do educando; a dialogicidade, em que o educador dá voz ao educando e com ele estabelece diálogo; a preparação do conteúdo programático que deve ser feita em conjunto com os educandos, para que haja produção de sentido; e, por fim, a consciência de que a verdadeira libertação procede do oprimido, só pode vir dele, precisa ser gerada nele e não nele depositada, como um bem que vem de fora. Sobre os aspectos principais dessa pedagogia versará, mais detidamente, o item a seguir. 


\subsection{Princípios da pedagogia para libertação}

O que nos parece indiscutivel é que, se pretendemos a libertação dos homens, não podemos começar por aliená-los ou mantê-los alienados. A libertação autêntica, que é a bumanização em processo, não é uma coisa que se deposita nos homens. Não é uma palavra a mais, oca, mitificante. É práxis, que implica na ação e na reflexão dos homens sobre o mundo para transformá-lo. (FREIRE, 1987, p. 38)

Em 1996, Paulo Freire escreve um livro intitulado Pedagogia da autonomia: saberes necessários à prática educativa, no qual ele apresenta uma série de saberes imprescindíveis para um efetivo ensino para a liberdade. Embora toda a sua obra reflita sua pedagogia, este livro é de essencial importância para a identificação dos princípios pedagógicos que amparam a educação freiriana, uma vez que nele Paulo Freire sumarizou, em 27 (vinte e sete) saberes que começam com a frase "Ensinar exige...", sua visão do que seria uma pedagogia para a libertação. Pedagogia da autonomia foi dividido em 3 (três) capítulos: Não há docência sem discência; Ensinar não é transferir conhecimento; e Ensinar é uma especificidade humana. Em cada capítulo Freire trabalhou 9 (nove) exigências para o ensino libertador.

Por razões de limitação de espaço, das 27 (vinte e sete) exigências da docência propostas por Freire, aqui serão trabalhadas apenas 8 (oito), as quais julgo mais apropriadas ou essenciais para que o professor de línguas lide com os desafios vividos em sala de aula, sobretudo quando esta é palco do discurso e ideologia dominantes associados à língua estrangeira de prestígio da atualidade: o inglês. Acredito que os princípios aqui elencados, quando postos em prática pelo educador, podem minimizar os efeitos nocivos da alienação cultural levando os alunos e o professor à reflexão crítica acerca de si e do outro, ajudando a promover uma relação dialógica e solidária entre os povos.

Embora este item se baseie preferencialmente no livro em questão, ele não estará isento de conter trechos das demais obras de Freire que confirmem o princípio pedagógico abordado. 


\subsubsection{Criticidade}

Ai a impossibilidade de vir a tornar-se um professor critico se, mecanicamente memorizador, é muito mais um repetidor cadenciado de frases e de idéias inertes do que um desafiador. (FREIRE, 1996, p. 14)

De todas as virtudes necessárias à docência, esta é a mais importante para o combate à alienação. E nesse processo o professor tem papel central, visto que, em sua prática, pode tolher ou incentivar a curiosidade do aluno e, ainda, mantê-la ingênua ou promovê-la à crítica. "Precisamente por que a promoção da ingenuidade para a criticidade não se dá automaticamente, uma das tarefas precípuas da prática educativa-progressista é exatamente o desenvolvimento da curiosidade crítica, insatisfeita, indócil” (FREIRE, 1996, p. 18). É esta curiosidade que deixou de se associar ao senso comum, ou seja, a curiosidade crítica, que devolve ao indivíduo o papel de sujeito do e no mundo, assim como sujeito da e na sua aprendizagem.

Ao investir no desenvolvimento crítico do aluno, o professor está investindo, na verdade, em dois conhecimentos essenciais ao indivíduo: a consciência da realidade que o cerca e a autoconsciência. Esse investimento seria, segundo Freire (1987, p. 57), o "ponto de partida do processo educativo, ou da ação cultural de caráter libertador". Para isso, o professor deve “[e]stimular a pergunta, a reflexão crítica sobre a própria pergunta, o que se pode pretender com esta ou com aquela pergunta em lugar da passividade em face das explicações discursivas do professor, espécies de respostas a perguntas que não foram feitas" (FREIRE, 1996, p. 52). Freire insiste que a educação "bancária" ou mecanicista é um ato de narrar contínuo que responde a perguntas que não foram feitas e, por isso, nesse tipo de abordagem pedagógica, não se aprende, se decora. Contrapondo as duas educações, a "bancária" e a libertadora, Freire (1987, p. 41) argumenta:

A primeira "assistencializa"; a segunda, criticiza. A primeira, na medida em que, servindo à dominação, inibe a criatividade e, ainda que não podendo matar a intencionalidade da consciência como um desprender-se ao mundo, a "domestica", nega os homens na sua vocação ontológica e histórica de humanizar-se. A segunda, na medida em que, servindo à libertação, se funda na criatividade e estimula a 
reflexão e a ação verdadeiras dos homens sobre a realidade, responde à sua vocação, como seres que não podem autenticar-se fora da busca e da transformação criadora.

A criticidade, como habilidade imprescindível ao sujeito, é virtude para a vida, útil em todas as esferas de relação humana. Ela é o antídoto para a ingenuidade alienante e paralisante, é a força que desvela a ideologia e permite a libertação.

Assim é que, enquanto a prática bancária, como enfatizamos, implica numa espécie de anestesia, inibindo o poder criador dos educandos, a educação problematizadora, de caráter autenticamente reflexivo, implica num constante ato de desvelamento da realidade. A primeira pretende manter a imersão; a segunda, pelo contrário, busca a emersão das consciências, de que resulte sua inserção crítica na realidade. (FREIRE, 1987, p. 40)

\subsubsection{Reflexão crítica sobre a prática}

A reflexão crítica sobre a prática se torna uma exigência da relação Teoria/Prática sem a qual a teoria pode ir virando blábláblá e a prática, ativismo. (FREIRE, 1996, p. 11)

A reflexão, o ato de pensar e teorizar sobre o fazer docente, é de caráter essencial para avaliação do que se faz; enquanto a prática é, ao mesmo tempo, causa e efeito do pensar. Causa porque se reflete sobre o que se faz, e efeito porque a ação se transformará a depender das conclusões do pensar.

Todo professor precisa refletir criticamente sobre sua prática, bem como praticar o que se refletiu. Isto implica em se enxergar exatamente como é, num processo reflexivo intenso capaz de gerar transformação prática e, espera-se, para melhor. Só um professor engajado na reflexão crítica sobre sua docência pode ser exemplo para que o seu aluno também reflita sobre sua aprendizagem e ambos, em conjunto, construam a prática educativa. O que é necessário, para ambos, de acordo com Freire (1996, p. 22) é “possibilitar, que, voltando-se sobre si mesma, através da reflexão sobre a prática, a curiosidade ingênua, percebendo-se como tal, se vá tornando crítica". Ele continua: 
A prática docente crítica, implicante do pensar certo, envolve o movimento dinâmico, dialético, entre o fazer e o pensar sobre o fazer. [...] Por isso, é fundamental que, na prática da formação docente, o aprendiz de educador assuma que o indispensável pensar certo não é presente dos deuses nem se acha nos guias de professores que iluminados intelectuais escrevem desde o centro do poder, mas, pelo contrário, o pensar certo que supera o ingênuo tem que ser produzido pelo próprio aprendiz em comunhão com o professor formador. [...] Por isso é que, na formação permanente dos professores, o momento fundamental é o da reflexão crítica sobre a prática. É pensando criticamente a prática de hoje ou de ontem que se pode melhorar a próxima prática. O próprio discurso teórico, necessário à reflexão crítica, tem de ser tal modo concreto que quase se confunda com a prática. (FREIRE, 1996, p. 22)

É esta habilidade de refletir criticamente sobre a prática adotada que dá ao docente e ao aluno a capacidade de, ao autocriticar-se, mudar, melhorar, crescer.

\subsubsection{Reconhecimento e assunção da identidade cultural}

Às vezes, mal se imagina o que pode passar a representar na vida de um aluno um simples gesto do professor. O que pode um gesto aparentemente insignificante valer como força formadora ou como contribuição à do educando por si mesmo. (FREIRE, 1996, p. 24)

O terceiro princípio a ser destacado diz respeito ao reconhecimento e à aceitação do outro e de si enquanto sujeitos culturais sem que isso acarrete em desprestígio e/ou humilhação. Afinal, a “assunção de nós mesmos não significa a exclusão dos outros. É a "outredade" do "não eu", ou do tu, que me faz assumir a radicalidade de meu eu" (FREIRE, 1996, p. 23 e 24). O professor precisa estar consciente da sua própria identidade, do lugar de onde fala, da história que carrega, dos costumes que vive e, porque vive, transmite, exemplifica. Com essa assunção própria, se torna capaz de enxergar no outro a igual existência de uma história e de uma identidade cultural. Segundo Freire (1996, p. 24),

[a] questão da identidade cultural, de que fazem parte a dimensão individual e a de classe dos educandos cujo respeito é absolutamente fundamental na prática educativa progressista, é problema que não pode ser desprezado. Tem que ver diretamente com a assunção de nós por nós mesmos. É isso que o puro treinamento do professor 
não faz, perdendo-se e perdendo-o na estreita e pragmática visão do processo.

Quando há espaço na sala de aula para o assumir-se e o aceitar-se e, assim, aos outros, o ambiente se torna propício à aprendizagem, pois já não há receio de expressar-se enquanto sujeito. Sendo essa uma "das tarefas mais importantes da prática educativo-crítica", a de "propiciar as condições em que os educandos em relação uns com os outros e todos com o professor ou a professora ensaiam a experiência profunda de assumir-se" (FREIRE, 1996, p. 23). Não se pode esquecer, contudo, das forças conflitantes presentes na educação mecanicista que despreza a assunção dos sujeitos ao relegá-los à posição de meros objetos de ensino. Ou seja,

[a] experiência histórica, política, cultural e social dos homens e das mulheres jamais pode se dar "virgem" do conflito entre as forças que obstaculizam a busca da assunção de si por parte dos indivíduos e dos grupos e das forças em favor daquela assunção. A formação docente que se julgue superior a essas "intrigas" não faz outra coisa senão trabalhar em favor dos obstáculos. A solidariedade social e política de que precisamos para construir a sociedade menos feia e menos arestosa, em que podemos ser mais nós mesmos, tem na formação democrática uma prática de real importância. A aprendizagem da assunção do sujeito é incompatível com o treinamento pragmático ou com o elitismo autoritário dos que se pensam donos da verdade e do saber articulado. (FREIRE, 1996, p. 24)

A educação para a liberdade vê na assunção da identidade cultural, ou seja, do sujeito enquanto totalidade, com emoções, valores e história, um caminho para a formação integral. Pois enxerga no professor não um "dador de aula", mas um ser humano que, em relação com seus educandos, conhece e é conhecido, forma e é formado, educa e é educado.

\subsubsection{Apreensão da realidade}

O ponto de partida deste movimento está nos homens mesmos. Mas, como não há homens sem mundo, sem realidade, o movimento parte das relações homensmundo. Dai que este ponto de partida esteja sempre nos homens no seu aqui e 
Perceber a realidade significa dizer pelo menos duas coisas. A primeira é que o professor precisa estar ciente da sua realidade, quem ele é, qual é a sua função enquanto docente e qual é o contexto que o cerca. Deve saber também que a sua presença na sala de aula pode ser auxiliadora ou perturbadora para seus educandos. A segunda é que a realidade que cerca os educandos deve ser a promotora e fornecedora dos conteúdos a serem trabalhados em sala de aula. Conteúdos alheios à realidade do educando raramente se transformam em aprendizado útil para vida.

Então, é preciso que se saiba, inicialmente, que a educação só existe porque, enquanto homens e mulheres,

[...] somos os únicos seres que, social e historicamente, nos tornamos capazes de aprender. Por isso, somos os únicos em que aprender é uma aventura criadora, algo, por isso mesmo, muito mais rico do que meramente repetir a lição dada. Aprender para nós é construir, reconstruir, constatar para mudar, o que não se faz sem abertura ao risco e à aventura do espírito. (FREIRE, 1996, p. 41)

Assim, aprender tem a ver com compreender a realidade, assimilá-la, para só então poder transformá-la. Educar-se e ser educado não é, portanto, um ato passivo, mas ativo. "A capacidade de aprender, não apenas para nos adaptar mas sobretudo para transformar a realidade, para nela intervir, recriando-a, fala de nossa educabilidade em um nível distinto do nível do adestramento dos outros animais ou do cultivo das plantas" (FREIRE, 1996, p. 41). Ensinar exige apreender a sua própria realidade enquanto docente e, claro, a realidade do discente, visto que um não existe sem o outro. Significa também saber que,

[c]omo professor, se minha opção é progressista e venho sendo coerente com ela, se não me posso permitir a ingenuidade de pensarme igual ao educando, de desconhecer a especificidade da tarefa do professor, não posso, por outro lado, negar que o meu papel fundamental é contribuir positivamente para que o educando vá sendo o artífice de sua formação com a ajuda necessária do educador. (FREIRE, 1996, p. 42) 
A compreensão crítica da realidade, e não ingênua, habilita o professor em sua tarefa de educar para a vida, de formar cidadãos conscientes e críticos, capazes de aprender, ou seja, de intervir ativamente na realidade. Pode-se afirmar, então, que

[...] toda prática educativa demanda a existência de sujeitos, um que, ensinando, aprende, outro que, aprendendo, ensina, daí o seu cunho gnosiológico; a existência de objetos, conteúdos a serem ensinados e aprendidos; envolve o uso de métodos, de técnicas, de materiais; implica, em função de seu caráter diretivo, objetivo, sonhos, utopias, ideais. Daí a sua politicidade, qualidade que tem a prática educativa de ser política, de não poder ser neutra. (FREIRE, 1996, p. 41)

O segundo aspecto da apreensão da realidade diz respeito à escolha dos conteúdos programáticos a serem discutidos em classe. Segundo Freire, para um ensino e aprendizagem efetivos, eles devem partir da realidade e seu objetivo deve ser o de problematizá-la, a fim de posteriormente respondê-la, transformá-la. Ele afirma:

É na realidade mediatizadora, na consciência que dela tenhamos educadores e povo, que iremos buscar o conteúdo programático da educação. O momento deste buscar é o que inaugura o diálogo da educação como prática da liberdade. É o momento em que se realiza a investigação do que chamamos de universo temático do povo ou o conjunto de seus temas geradores. Esta investigação implica, necessariamente, numa metodologia que não pode contradizer a dialogicidade da educação libertadora. Daí que seja igualmente dialógica. Daí que, conscientizadora também, proporcione, ao mesmo tempo, a apreensão dos "temas geradores" e a tomada de consciência dos indivíduos em torno dos mesmos. (FREIRE, 1987, p. 50)

Na visão de Freire, é a realidade que mediatiza a aprendizagem, pois não existe ensino no vácuo. Os homens estão no mundo e com o mundo, assim ensinam e aprendem, questionam e respondem, educam e são educados. O princípio de apreensão da realidade depende diretamente de outro princípio, sobre o qual se falará mais tarde: a dialogicidade. Sem ela será impossível escolher o conteúdo programático de forma democrática e não raras vezes as aulas serão monólogos e narrações que dificilmente produzirão sentido. Freire (1987, p. 47) explica como ocorre essa escolha nos dois modelos de educação:

Daí que, para esta concepção como prática da liberdade, a sua dialogicidade comece, não quando o educador-educando se encontra 
com os educandos-educadores em uma situação pedagógica, mas antes, quando aquele se pergunta em torno do que vai dialogar com estes. Esta inquietação em torno do conteúdo do diálogo é a inquietação em torno do conteúdo programático da educação. Para o "educador-bancário", na sua antidialogicidade, a pergunta, obviamente, não é a propósito do conteúdo do diálogo, que para ele não existe, mas a respeito do programa sobre o qual dissertará a seus alunos. E a esta pergunta responderá ele mesmo, organizando seu programa. Para o educador-educando, dialógico, problematizador, o conteúdo programático da educação não é uma doação ou uma imposição - um conjunto de informes a ser depositado nos educandos, mas a revolução organizada, sistematizada e acrescentada ao povo, daqueles elementos que este lhe entregou de forma desestruturada.

Dessa forma, para uma educação libertadora, a escolha dos conteúdos só pode ser feita com os sujeitos dessa educação em conjunto: professor e alunos. E são estes que, no diálogo com o docente, lhe entregarão os temas e questões da sua realidade para que o professor os organize e lhes apresente o seu olhar, permitindo-os, igualmente, que reflitam e falem sobre eles. A maneira como deve ser feita a organização do conteúdo programático, segundo a educação para a liberdade, é descrita por Freire (1987, p. 49):

Será a partir da situação presente, existencial, concreta, refletindo o conjunto de aspirações do povo, que poderemos organizar o conteúdo programático da situação ou da ação política, acrescentemos. $\mathrm{O}$ que temos de fazer, na verdade, é propor ao povo, através de certas contradições básicas, sua situação existencial, concreta, presente, como problema que, por sua vez, o desafia e, assim, lhe exige resposta, não só no nível intelectual, mas no nível da ação. Nunca apenas dissertar sobre ela e jamais doar-lhe conteúdos que pouco ou nada tenham a ver com seus anseios, com suas dúvidas, com suas esperanças, com seus temores. Conteúdos que, às vezes, aumentam estes temores. Temores de consciência oprimida. Nosso papel não é falar ao povo sobre a nossa visão do mundo, ou tentar impô-la a ele, mas dialogar com ele sobre a sua e a nossa. Temos de estar convencidos de que a sua visão do mundo, que se manifesta nas várias formas de sua ação, reflete a sua situação no mundo, em que se constitui. A ação educativa e política não pode prescindir do conhecimento crítico dessa situação, sob pena de se fazer "bancária" ou de pregar no deserto. Por isto mesmo é que, muitas vezes, educadores e políticos falam e não são entendidos. Sua linguagem não sintoniza com a situação concreta dos homens a quem falam. E sua fala é um discurso a mais, alienado e alienante. 
A decisão por compreender a realidade e agir nela para transformá-la é dever do qual o professor problematizador não pode se eximir.

\subsubsection{Segurança, competência profissional e generosidade}

\section{[...] a incompetência profissional desqualifica a autoridade do professor. (FREIRE, 1996, p. 56)}

Dentre as muitas virtudes do professor libertador, este subitem traz três que dialogam entre si: segurança, competência profissional e generosidade. O docente precisa estar seguro de si enquanto executor de seu papel educativo, sua segurança lhe confere autoridade e ambas se relacionam com uma outra competência, como explica Freire (1996, p. 56):

A segurança com que a autoridade docente se move implica uma outra, a que se funda na sua competência profissional. Nenhuma autoridade docente se exerce ausente desta competência. O professor que não leve a sério sua formação, que não estuda, que não se esforce para estar à altura de sua tarefa não tem força moral para coordenar as atividades de sua classe.

O professor não pode estar desatualizado, enferrujado e obsoleto, há que se renovar e se atualizar para que sua função não perca a razão de ser e sua ação no mundo, através da pedagogia, seja eficaz. Por competência profissional não se quer dizer, de forma alguma, conhecimento arrogante ou prepotente, ao contrário, só tem autoridade o docente que sabendo o que ensina, o ensina de forma humilde e gentil. Seu conhecimento não se torna empecilho à aprendizagem do outro, mas, em vez disso, o convida a aprender. Essa virtude docente é o que Freire chama de generosidade. Dentre as suas características está a humildade de se reconhecer conhecedor de algumas coisas e ignorante de outras e estar seguro de que essa assunção em nada lhe tirará a autoridade, pelo contrário, construirá uma ponte dialógica entre o educador e o educando que se perceberá igualmente conhecedor e ignorante. A esse respeito, disserta Freire (1996, p. 58): 
Posso saber pedagogia, biologia como astronomia, posso cuidar da terra como posso navegar. Sou gente. Sei que ignoro e sei que sei. Por isso, tanto posso saber o que ainda não sei como posso saber melhor o que já sei. E saberei tão melhor e mais autenticamente quanto mais eficazmente construa minha autonomia em respeito à todos outros.

A postura segura, porque sabe, e generosa, porque ignora, do professor frente aos educandos cria um ambiente altamente fértil para a aprendizagem. E assim, o "clima de respeito que nasce em relações justas, sérias, humildes, generosas, em que a autoridade docente e as liberdades dos alunos se assumem eticamente, autentica o caráter formador do espaço pedagógico" (FREIRE, 1996, p. 56 e 57).

Para concluir seu pensamento, Freire retorna à questão emitindo sua opinião de forma ainda mais veemente, quando diz:

[...] não é a minha arrogância intelectual a que fala de minha rigorosidade científica. Nem a arrogância é sinal de competência nem a competência é causa de arrogância. Não nego a competência, por outro lado, de certos arrogantes, mas lamento neles a ausência de simplicidade que, não diminuindo em nada seu saber, os faria gente melhor. Gente mais gente. (FREIRE, 1996, p. 92)

\subsubsection{Convicção de que a mudança é possível}

A educação para a liberdade só é realizável porque uma convicção a sustenta: a de que a mudança é possível. O professor que exerce sua função descrente da mudança presta um desserviço à sociedade. Imprime em seus alunos a comodidade e a vitimização, mantém-nos como objetos da história. Crer que a mudança é possível é enxergar a história

[...] como possibilidade e não como determinação. O mundo não é. O mundo está sendo. Como subjetividade curiosa, inteligente, interferidora na objetividade com que dialeticamente me relaciono, meu papel no mundo não é só o de quem constata o que ocorre mas também o de quem intervém como sujeito de ocorrências. Não sou apenas objeto da História mas seu sujeito igualmente. No mundo da História, da cultura, da política, constato não para me adaptar, mas para mudar. No próprio mundo físico minha constatação não me leva à impotência. [...] Há perguntas a serem feitas insistentemente por todos nós e que nos fazem ver a impossibilidade de estudar por 
estudar. De estudar descomprometidamente como se misteriosamente, de repente, nada tivéssemos que ver com o mundo, um lá fora e distante mundo, alheado de nós e nós dele. (FREIRE, 1996, p. 46)

O educador crítico deve promover perguntas e não se acovardar quando elas forem feitas. Perguntar é parte da construção crítica de conhecimento. Perguntas como "Em favor de que estudo? Em favor de quem? Contra que estudo? Contra quem estudo?” (FREIRE, 1996, p. 47). são extremamente importantes para, primeiro, compreender a realidade do contexto educativo com o qual se está lidando, e, só assim, poder intervir nela. A partir da certeza de que a mudança é uma possibilidade é que se pode planejar a ação político-pedagógica necessária à atividade docente.

Na pedagogia do oprimido, que é a da libertação, o trabalho do docente - crente na mudança - é o de desvincular a mente dos oprimidos da culpa pela situação que vivem, a qual lhes foi imposta pela ideologia dominante, como atesta Freire (1996, p. 50):

É importante ter sempre claro que faz parte do poder ideológico dominante a inculcação nos dominados da responsabilidade por sua situação. Daí a culpa que sentem eles, em determinado momento de suas relações com o seu contexto e com suas classes dominantes por se acharem nesta ou naquela situação desvantajosa.

Daí que a admirável tarefa do educador seja correspondente à “'expulsão’ do opressor de 'dentro' do oprimido, enquanto sombra invasora. Sombra que, expulsa pelo oprimido, precisa de ser substituída por sua autonomia e sua responsabilidade" (FREIRE, 1996, p. 51).

\subsubsection{Reconhecer que a educação é ideológica}

A educação como prática da dominação, que vem sendo objeto desta crítica, mantendo a ingenuidade dos educandos, o que pretende, em seu marco ideológico, (nem sempre percebido por muitos dos que a realizam) é indoutriná-los no sentido de sua acomodação ao mundo da opressão. (FREIRE, 1987, p. 38) 
A educação, como todo discurso, é ideológica por natureza. Não existe neutralidade na educação, pois não existe neutralidade no homem. Justamente por ser uma especificidade humana, a educação é política e, portanto, ideológica, como atesta Freire (1996, p. 68 e 69):

É na diretividade da educação, esta vocação que ela tem, como ação especificamente humana, de endereçar-se até sonhos, ideais, utopias e objetivo, que se acha o que venho chamando politicidade da educação. A qualidade de ser política, inerente à sua natureza. É impossível, na verdade, a neutralidade da educação. E é impossível, não porque professoras e professores baderneiros e subversivos o determinem. A educação não vira política por causa da decisão deste ou daquele educador. Ela é política.

Reconhecer esta qualidade ideológica da educação é, portanto, um saber subsequente ao princípio da apreensão da realidade, é enxergar a sociedade, o entorno da ação pedagógica como um todo, é sair da zona de conforto, é pisar os pés no chão, é saber que “[n]eutra, indiferente a qualquer destas hipóteses, a da reprodução da ideologia dominante ou de sua contestação, a educação jamais foi, é, ou pode ser” (FREIRE, 1996, p. 61). A educação pode tanto servir aos interesses dominantes, quanto aos oprimidos. A razão disso pode ser encontrada no trecho abaixo:

Se a educação não é a chave das transformações sociais, não é também simplesmente reprodutora da ideologia dominante. O que quero dizer é que a educação nem é uma força imbatível a serviço da transformação da sociedade, porque assim eu queira, nem tampouco é a perpetuação do "status quo" porque o dominante o decrete. $\mathrm{O}$ educador e a educadora críticos não podem pensar que, a partir do curso que coordenam ou do seminário que lideram, podem transformar o país. Mas podem demonstrar que é possível mudar. $\mathrm{E}$ isto reforça nele ou nela a importância de sua tarefa político-pedagógica. (FREIRE, 1996, p. 70)

Assim, enquanto há educadores e oprimidos comprometidos com a causa da libertação aqui, há outros alheios a esse movimento acolá, fazendo com que a educação como um todo contenha essa contraditoriedade. E o agravante é que, num contexto opressivo, até mesmo a decisão que alguém venha a ter de "permanecer neutro" é um ato político e 
ideológico, não há como se eximir disso, pois, como disse Freire (1996, p. 70): "'Lavar as mãos’ em face da opressão é reforçar o poder do opressor, é optar por ele”.

Então, o professor inconsciente da realidade opressora é um docente alienado e alienador, pois essa realidade nunca será objeto de discussão em suas aulas como tentativa de transformação das consciências para, enfim, transformar a realidade. Para o professor libertador, no entanto, a consciência da realidade opressiva, da ideologia que domina a sociedade e da responsabilidade ideológica do seu papel enquanto educador é de suma importância.

O reconhecimento do caráter ideológico da educação passa, claro, pela formação de professores. É lá que as questões sociais devem ser atreladas aos conteúdos discutidos em sala de aula, é na formação que os professores aprendem o que é ensinar e para que serve a educação. Se nos cursos de Letras, ou de licenciaturas em geral, não houver a preocupação de formar docentes críticos e engajados na educação contextualizada e inserida na realidade local, o equívoco da ingenuidade alienante começou das bases. Identificar a origem do erro, no entanto, não exime o docente da responsabilidade que tem pela sua práxis pedagógica e, uma vez que sua consciência foi liberta pela reflexão e pela prática da criticidade, repousa sobre ele o dever de, igualmente, educar os seus alunos com base nesses princípios. Freire (1996, p. 87) defende, em suas palavras, que a "formação dos professores e das professoras devia insistir na constituição deste saber necessário e que me faz certo desta coisa óbvia, que é a importância inegável que tem sobre nós o contorno ecológico, social e econômico em que vivemos".

Quando o professor se conscientiza da importância de se tratar a realidade em sala de aula, surgem as dúvidas sobre como se posicionar diante dos educandos. Há certo receio em assumir uma postura firme, em defender seus ideais e convicções, justamente porque se convencionou afirmar que a escola é um espaço neutro. Para os docentes com dificuldades de posicionar-se ideologicamente, Freire (1996, p. 42, grifo nosso) aconselha:

Primordialmente, minha posição tem de ser a de respeito à pessoa que queira mudar ou que recuse mudar. Não posso negar-lhe ou esconder-lhe minha postura mas não posso desconhecer o seu 
direito de rejeitá-la. Em nome do respeito que devo aos alunos não tenho por que me omitir, por que ocultar a minha opção política assumindo uma neutralidade que não existe. Esta, a omissão do professor em nome do respeito ao aluno, talvez seja a melhor maneira de desrespeitá-lo. O meu papel, ao contrário, é o de quem testemunha o direito de comparar, de escolher, de romper, de decidir e estimular a assunção deste direito por parte dos educandos.

Assim, o professor que prefere se omitir é porque ainda não percebeu que mesmo esse ato de omissão é uma postura igualmente política e ideológica. O educador, ao assumir-se ideologicamente, o que faz é permitir, pelo próprio exemplo, que o aluno também se assuma, que ideias sejam compartilhadas e assuntos debatidos, sem medo do confronto respeitoso, em um livre expressar-se.

$\mathrm{Na}$ luta pelo fim da opressão, é mister que não se duvide do poder que possui a educação de intervir no mundo e de revolucioná-lo de dentro para fora. A educação para a liberdade começa nas consciências e vai tomando corpo, se assumindo e agindo socialmente. A ação pedagógica libertadora é, por essência, um acontecimento que se passa dentro e fora da sala de aula e seus frutos são imensuráveis. Por isso a tarefa do professor não pode se resumir à simples narração de conteúdos vazios e inférteis sob pena de se fazer em pequenez a grandeza dessa profissão. Para intervir no mundo, todo docente precisa de ideais. No trecho abaixo Freire (1996, p. 63 e 64) resume os seus:

Sou professor a favor da decência contra o despudor, a favor da liberdade contra o autoritarismo, da autoridade contra a licenciosidade, da democracia contra a ditadura de direita ou de esquerda. Sou professor a favor da luta constante contra qualquer forma de discriminação, contra a dominação econômica dos indivíduos ou das classes sociais. Sou professor contra a ordem capitalista vigente que inventou esta aberração: a miséria na fartura. Sou professor a favor da esperança que me anima apesar de tudo.

\subsubsection{Disponibilidade para o diálogo}

Todos os princípios pedagógicos libertadores aqui já expostos estão fundamentados no último princípio a ser discutido neste subitem: a dialogia. A educação problematizadora 
é, por essência, dialógica. Pressupõe a existência de sujeitos em constante interação e abertos ao outro, a escutá-lo e, por isso, com ele falar, ou seja, pressupõe diálogo. Freire (1987, p. 58) cita uma das consequências práticas da pedagogia dialógica:

Enquanto na prática "bancária” da educação, anti-dialógica por essência, por isto, não comunicativa, o educador deposita no educando o conteúdo programático da educação, que ele mesmo elabora ou elaboram para ele, na prática problematizadora, dialógica por excelência, este conteúdo, que jamais é “depositado", se organiza e se constitui na visão do mundo dos educandos, em que se encontram seus “temas geradores". Por tal razão é que este conteúdo há de estar sempre renovando-se e ampliando-se.

A disponibilidade para o diálogo, e as consequências que dele advém, dependem de uma virtude preciosa ao educador libertador: a humildade, que, como já discutido, não é produto da incompetência profissional, mas da generosidade do educador. "Não há [...] diálogo, se não há humildade. A pronúncia do mundo, com que os homens o recriam permanentemente, não pode ser um ato arrogante” (FREIRE, 1987, p. 46). Assim, a dialogicidade que Freire defende depende da contemplação de virtudes outras que tornam o indivíduo tolerante e aberto ao próximo. A esse respeito, Freire (1987, p. 46) se questiona:

Como posso dialogar, se alieno a ignorância, isto é, se a vejo sempre no outro, nunca em mim? Como posso dialogar, se me admito como um homem diferente, virtuoso por herança, diante dos outros, meros "isto", em quem não reconheço outros eu? Como posso dialogar, se me sinto participante de um "gueto" de homens puros, donos da verdade e do saber, para quem todos os que estão fora são "essa gente", ou são "nativos inferiores"?

O diálogo só é possível quando, despido de preconceitos e discriminações, o educador primeiramente pratica a autocrítica, se enxerga assumindo seus erros e acertos para, posteriormente, conseguir ver o outro, ainda que em posição hierarquicamente inferior, como um igual. Por isso Freire (1987, p. 45) afirma que o amor é a base do diálogo:

Sendo fundamento do diálogo, o amor é, também, diálogo. Daí que seja essencialmente tarefa de sujeitos e que não possa verificar-se na relação de dominação. Nesta, o que há é patologia de amor: sadismo em quem domina; masoquismo nos dominados. Amor, não, porque 
é um ato de coragem, nunca de medo, o amor é compromisso com os homens. Onde quer que estejam estes, oprimidos, o ato de amor está em comprometer-se com sua causa. A causa de sua libertação. Mas, este compromisso, porque é amoroso, é dialógico.

O professor problematizador não se pode furtar ao diálogo, não pode achar que sua práxis é um ato solitário e monológico, mas, comprometido dialogicamente com seus educandos, constroem juntos o conhecimento. Ser dialógico é saber que seu pensar não será jamais uma imposição e que o conhecimento não se passa, mas se constrói em conjunto.

A tarefa coerente do educador que pensa certo é, exercendo como ser humano a irrecusável prática de inteligir, desafiar o educando com quem se comunica e a quem comunica, produzir sua compreensão do que vem sendo comunicado. Não há inteligibilidade que não seja comunicação e intercomunicação e que não se funde na dialogicidade. (FREIRE, 1996, p. 21)

Ser dialógico não significa, no entanto, a inexistência de momentos de exposição de conteúdos; significa que o espaço discursivo está aberto a intervenções concordantes ou discordantes às quais não se faltará com o respeito. É, portanto, um abrir-se a questionamentos, à curiosidade dos alunos e a sua própria, é tornar o ambiente escolar propício à aprendizagem verdadeira, aquela que é construída pelo educando em sua autonomia e pelo educador como auxiliador nesse processo. Freire (1996, p. 52) atesta:

A dialogicidade não nega a validade de momentos explicativos, narrativos em que o professor expõe ou fala do objeto. O fundamental é que o professor e alunos saibam que a postura deles, do professor e dos alunos, é dialógica, aberta, curiosa, indagadora e não apassivada, enquanto fala ou enquanto ouve. O que importa é que professor e alunos se assumam epistemologicamente curiosos.

A partir da exposição dos princípios pedagógicos para a liberdade, é possível depreender que a pedagogia freiriana volta-se para as questões reais da sociedade, não tendo como pretensão alienar os educandos, nem acomodá-los à situação em que vivem, sejam eles da classe que domina - os opressores - ou da classe dominada - os oprimidos. Segundo Freire, ambos precisam de libertação e a educação pode ser esse caminho se respeitadas 
certas exigências que a pedagogia crítica demanda do educador. Freire (1987, p. 38) diz que, ao denunciar a opressão existente,

[...] não esperamos que as elites dominadoras renunciem à sua prática. Seria demasiado ingênuo esperá-lo. Nosso objetivo é chamar a atenção dos verdadeiros humanistas para o fato de que eles não podem, na busca da libertação, servir-se da concepção - bancáriall, sob pena de se contradizerem em sua busca. Assim como também não pode esta concepção tornar-se legado da sociedade opressora à sociedade revolucionária.

Partindo da crença que depositam nos homens, pelo simples fato de serem humanos - capazes, portanto, de pensar, escolher, aprender, transformar e se transformar - os educadores libertadores, em diálogo com os homens, permitem-nos reapropriarem-se da habilidade de serem sujeitos da história, habilidade que lhes foi negada pela opressão. Por fim,

[é] preciso que saibamos que, sem certas qualidades ou virtudes como amorosidade, respeito aos outros, tolerância, humildade, gosto pela alegria, gosto pela vida, abertura ao novo, disponibilidade à mudança, persistência na luta, recusa aos fatalismos, identificação com a esperança, abertura à justiça, não é possível a prática pedagógico-progressista, que não se faz apenas com ciência e técnica. (FREIRE, 1996, p. 75)

\section{Finalizando o diálogo aqui, abrindo espaço para diálogos acolá}

Nosso espaço de conversa aqui se finda, mas as reflexões aqui levantadas guardam consigo grande potencial para uma enorme teia de novos diálogos se iniciem. Gostaria de finalizar nosso diálogo com um desafio. Se você, caro(a) leitor(a), é professor(a), se permita experimentar na prática esses princípios freireanos, explorando suas possibilidades e desfrutando dos resultados. Invista em sua prática pedagógica, tornando-a cada vez mais crítica e comprometida com a transformação social. Caminhemos juntos em direção a um ensino que extrapole os conteúdos e alcance os indivíduos. 


\section{FREIREAN PRINCIPLES FOR TRAINING \\ A LIBERATING LANGUAGE TEACHER}

ABSTRACT: The undertaken discussions in this article relate to Freirean pedagogical requirements for a liberating teacher training. In such controversial times in Brazilian educational scenario, I present and discuss in this essay eight teacher training knowledges, which I call Freirean principles, when reflecting on a critical educator practice whose project of society is directed towards the formation of critical citizens capable of reading their local social reality and of transforming it. Anchored in Paulo Freire's work, I theoretically discuss the following principles: Criticity; Critical reflection on practice; Recognition and assumption of cultural identity; Apprehension of reality; Security, professional competence and generosity; Conviction that change is possible; Recognize that education is ideological; and Availability for dialogue. Freire's life and work challenge all of us teachers to construct our pedagogical practice in a coherent, reflective and sociopolitically committed way.

KEYWORDS: Freirean principles; Liberating pedagogy; Teacher training.

\section{REFERÊNCIAS}

FREIRE, Paulo Reglus Neves. Educação como prática da liberdade. Rio de Janeiro: Paz e Terra, 1967. . Pedagogia do oprimido. 17. ed. Rio de Janeiro: Paz e Terra, 1987. Versão digital. . Pedagogia da autonomia: Saberes necessários à prática educativa. Rio de Janeiro: Paz e Terra, 1996.

Recebido em: 31/05/2019. Aprovado em: 31/07/2019. 